\title{
Interrelation between birth weight, body mass index, insulin resistance, C-Reactive Protein-hs, adiponectin and leptin in children (Age 10 to 20 years)
}

\author{
Thakre R.R. ${ }^{1}$, Naik S.S. ${ }^{2}$, Abhang A.S. ${ }^{3}$ \\ ${ }^{1}$ Ravi R Thakre, Research Scholar, B.J. Medical College Pune, ${ }^{2}$ Dr. S. S. Naik, Head of biochemistry and \\ Endocrinology, K.E.M. Hospital Pune, ${ }^{3}$ Dr. S. A. Abhang, Professor of Biochemistry, B.J. Medical College \\ Sassoon Government Hospital Pune, Maharashtra, India.
}

Address for Correspondence: Ravi Raghunath Thakre, Email: ravi.raghunath.thakre@gmail.com

\begin{abstract}
Background: India is projected to have one of the largest populations of obese children over the next decade. Birth weight reflects maternal nutrition and fetal programming which may be a leading cause of obesity. Adipokines also play an important role in development of obesity, inflammation and insulin resistance. The aim of this study is to evaluate serum adiponectin, leptin in Indian school-going children in the age group of 10-20 years. This study also describes distribution of adipokines concentrations and examines the inter-relationship of adipokines with birth weight, body mass index (BMI), C - reactive protein high sensitive (CRP-hs), and insulin resistance (IR). Methods: A cross-sectional study involves a total of 200 school going children between the age group of 10-20 yrs. Fasting plasma glucose, insulin, adiponectin, leptin, CRP-hs, were measured for the school going children and birth weight was recorded. BMI was defined as weight $(\mathrm{kg})$ divided by height $(\mathrm{m})$ squared. Insulin resistance was assessed using the homeostasis model (HOMA-IR). Results: Children with higher BMI had higher birth weight and insulin. Obese children had lower adiponectin and higher leptin levels suggestive of an inverse association with adipokines. Children with higher BMI had lower glucose. Conclusion: Leptinan indicator of fat mass induces insulin resistance and inflammation. The derangement observed in all related parameters including insulin resistance, leptin, adiponectin and CRP-hs were due to high fat mass. However, the relationship of birth weight and adipokines needs further evaluation.
\end{abstract}

Keywords: Birth weight, BMI, Insulin resistance, CRP-hs, Adiponectin and Leptin

\section{Introduction}

A positive relationship is reported between birth weight and BMI in childhood or adulthood. Adults with low birth weight were found to have an increased risk of developing diabetes, hypertension, coronary heart disease and stroke in adulthood [1]. This focused attention on the importance of intrauterine life as a determinant of later health. The link between intrauterine exposure, obesity and type 2 diabetes has been explained by the concept of fetal programming [2,3]. In 1991 Hales \& Barker reported that low birth weight and thinness at birth are risk factors for type 2 diabetes [4,5]. Obesity is the result of both environmental and

Manuscript received: $17^{\text {th }}$ November 2017

Reviewed: $27^{\text {th }}$ November 2017

Author Corrected: $4^{\text {th }}$ December 2017

Accepted for Publication: $11^{\text {th }}$ December 2017 genetic factors. Obesity is associated with low insulin sensitivity and high plasma leptinconcentrations [6]. Indians are also reported to have low body mass index but higher adiposity [7]. Rising prevalence of obesity in developing countries is attributed to rapid sedentary life style and reduced physical activity.

Genetically, childhood obesity in Asian Indians is upcoming cause of insulin resistance, diabetes and inflammation. Data analysis suggests birth weight and obesity in adolescent age are interrelated. Birth weight indicates the maternal nutrition and fetal programming. Obesity is one of the factors for insulin resistance, which is better understood by studying the supplementary factors influencing 
insulin resistance and inflammation. Adipokines may contribute to the development of obesity and insulin resistance. Reduction in adiponectin plays a primary role in the development of insulin resistance. Adipokines such as leptin, resistin, TNF- $\alpha$, adipsin, visfatin, interlukines- 6 and adiponectin are biological active molecules produced by adipose tissue. Limited data suggests that adiponectin is 33\% lower in obese children with diabetes than those without diabetes [8].

Some pediatric studies [8-16] have shown a negative association between adiponectin and various measures of insulin resistance (IR), but the association was independent of adiposity in only five of these reports [8-12]. Puberty leads to changes in body fat, contributes to IR [12], and may modify the association between adiponectin and IR.

The present study is undertaken to evaluate serum adiponectin, leptin in Indian school children; to describe distribution of adiponectin concentrations in the age group of $10-20$ years and to examine the interrelationship of adiponectin with birth weight, BMI, CRP-hs, leptin and insulin resistance.

\section{Methods}

Subjects:This study involves a total of 200 school going children between the age group of 10-20 yrs. The children participating in this study mostly came from educated families who lived in an urban setting with relatively middle socio-economic background.

Design-A cross-sectional studyand total students were categorized into two groups, based on their BMI: group I (120 subjects) as non-obese subjects with a BMI $<25 \mathrm{~kg} / \mathrm{m}^{2}$, group II (80 subjects)as obese subjects with $\mathrm{BMI} \geq 25 \mathrm{~kg} / \mathrm{m}^{2}$ respectively. Obesity was defined as BMI $\geq 25 \mathrm{~kg} / \mathrm{m}^{2}[17,18$, and 19]. All the participants have given their informed consent and the study was approved by the ethics committee of B. J. Medical College \& Sassoon General Hospital, Pune (Ref letter no. BJMC/IEC/Pharmac/D1210156-58).

Inclusion criteria- All the willing school going subjects in the age group of 10-20 years children not suffering from any major illness.

Exclusion criteria-It consists of subjects not knowing the birth weight, those with diabetes mellitus or other chronic illnesses, and those on medicationsat the time of the study.

Participants-The participants were boys and girls who represent the middle socio-economic population of Pune School.

Indexes- The BMI was calculated as body weight $(\mathrm{kg}) /$ height $(\mathrm{m})^{2}$. The homeostatic index of insulin resistance (HOMA-IR) was calculated as follows: HOMA-IR = fasting glucose $(\mathrm{mg} / \mathrm{dL}) \quad \mathrm{X}$ fasting insulin $(\mathrm{uU} / \mathrm{mL}) / 405[20]$.

Biochemical methods- Blood samples of $10 \mathrm{ml}$ were collected in the morning by venous puncture after overnight fasting (at least $08-12$ hours of fasting) to measure the following biochemical parameters: serum insulin, adiponectin, leptin, CRP-hs concentration were measured by enzyme linked immunoassay respectively (ELISA; Calbiotek, Biovendor, and Diagnostics Biochem). Glucose was measured by GOD-POD method.

Statistical Method- Statistical Analysis was performed using Statistical Package of Social Sciences (SPSS, version 12). Means, Medians and Coefficient of Variation (CV) were calculated for all parameters. Independent Student's t test was used to perform gender comparisons as well as between obese and non-obese children. Pearson correlation coefficient $(r)$ was used for correlation analysis. A $p$ value $\leq 0.05$ was considered significant and $(\mathrm{p}<0.001)$ highly significant.

\section{Results}

Females had higher BMI $(\mathrm{p}<0.05)$, lower adiponectin and higher fat mass as compared to males. $50 \%$ of children had low birth-weight. There was significant gender difference in plasma leptinand adiponectin concentration. Obese children had higher leptin $(\mathrm{p}<0.0001)$ and lower adiponectin $(\mathrm{p}<0.001)$ concentration. $40 \%$ of the children were obese but none was diabetic. Low birth weight children remained thin at adolescence. There was significant inverse correlation between leptin and adiponectin. Glycemic status was directly related to adiponectin andinversely related to fat mass. However, insulin resistance wasnot associated with fat mass (Table1). 


\section{Original Research Article}

Mean age of children studied was 13.6 years with $22.19 \mathrm{~kg} / \mathrm{m}^{2}$ BMI. Obese children were older than the nonobese children with higher birth weight. Obese children had lower glucose $(\mathrm{p}<0.05)$ and higher fat mass. Children belonged to medium Socio-economic status and physical activities were similar in all children. The significance remained similar after adjusting for gender (Table 1). Adiponectin was lower in obese groups as compared to the non- obese group. Birth weight was inversely associated with plasma adiponectin and glucose and directly with BMI at the time of study age. Inverse correlation has continued from birth to adolescent (Table 2).

BMI showed negative correlation with plasma glucose (0.01), Adiponectin (0.01) and positive with plasma insulin (0.05), leptin (0.01), birth weight and CRP-hs (0.01). Adiponectin showed negative co-relation with plasma insulin (0.05), HOMA-IR (0.05), CRP-hs (0.01), leptin (0.01) birth weight (0.01) and positively correlated with glucose $(0.05)$. Leptin showed positive co-relation with CRP-hs $(0.01)$ \& negative correlation with plasma glucose (0.05). Birth weight had positive co-relation with BMI \& negative co-relation with plasma glucose $(0.05) \&$ adiponectin (0.01). HOMA-IR showed positive co-relation to plasma glucose (0.01), insulin (0.01) (Table 3).

Table-1: Clinical characteristics of participants, by gender.

\begin{tabular}{|llll|}
\hline & Male (94) & Female (106) & Significance \\
\hline Variables & Mean & Mean & (p) value \\
\hline Age $($ years $)$ & $13.29 \pm 2.97$ & $13.93 \pm 2.898$ & 0.147 \\
\hline Weight $(\mathrm{Kg})$ & $49.83 \pm 22.89$ & $50.62 \pm 17.99$ & $0.004^{*}$ \\
\hline Height $(\mathrm{cm})$ & $147.65 \pm 16.89$ & $146.97 \pm 12.9$ & $0.005^{*}$ \\
\hline Birth Weight $(\mathrm{Kg})$ & $2.70 \pm 0.712$ & $2.63 \pm 0.67$ & 0.423 \\
\hline BMI $\left(\mathrm{Kg} / \mathrm{m}^{2}\right)$ & $21.66 \pm 6.172$ & $22.67 \pm 5.95$ & $0.045^{*}$ \\
\hline Glucose $(\mathrm{mg} / \mathrm{dL})$ & $90.97 \pm 18.93$ & $92.38 \pm 22.69$ & 0.652 \\
\hline Insulin $(\mathrm{IU} / \mathrm{mL})$ & $12.79 \pm 19.32$ & $15.25 \pm 19.77$ & 0.404 \\
\hline HOMA-IR & $2.99 \pm 4.49$ & $3.74 \pm 6.28$ & 0.361 \\
\hline CRP-hs $(\mathrm{ng} / \mathrm{mL})$ & $1286.29 \pm 1691.81$ & $1564.14 \pm 1994.48$ & 0.145 \\
\hline Adiponectin $(\mu \mathrm{g} / \mathrm{mL})$ & $48.44 \pm 16.58$ & $41.56 \pm 17.10$ & $0.007^{*}$ \\
\hline Leptin $(\mathrm{ng} / \mathrm{mL})$ & $10.92 \pm 13.04$ & $16.67 \pm 14.93$ & $0.007^{*}$ \\
\hline
\end{tabular}

Results are expressed as mean \pm standard deviation. Normal weight was defined as a body mass index (BMI) < $25 \mathrm{~kg} / \mathrm{m}^{2}$; Comparisons between genders was performed using Independent Samples T test.

* Significant

Table-2: Characteristics of obese and non-obese children $\left(\mathrm{Kg} / \mathrm{m}^{2}\right)$

\begin{tabular}{|llllll|}
\hline \multicolumn{1}{|c}{ Group (I) } & \multicolumn{1}{c}{ Group (II) } & & & & \\
\hline & Mean & Mean & Mean & Range & Significance \\
\hline Age $(\mathrm{Yrs})$ & 12.32 & 15.4 & 13.6 & $10-20$ & $0.026^{*}$ \\
\hline Birth weight $(\mathrm{Kg})$ & 2.58 & 2.80 & 2.67 & $1.0-4.6$ & 0.607 \\
\hline Mean BMI $\left(\mathrm{Kg} / \mathrm{m}^{2}\right)$ & 18.04 & 27.81 & 22.19 & $11.9-39.6$ & $0.0001^{*}$ \\
\hline Glucose $(\mathrm{mg} / \mathrm{dL})$ & 93.61 & 86.08 & 91.69 & $42-191$ & $0.032^{*}$ \\
\hline Insulin $(\mathrm{IU} / \mathrm{mL})$ & 13.18 & 15.15 & 14.02 & $0.20-148.1$ & 0.975 \\
\hline HOMA-IR & 3.341 & 3.42 & 3.36 & $0.0-51.9$ & 0.577 \\
\hline CRP-hs $(\mathrm{ng} / \mathrm{mL})$ & 868.86 & 2180.13 & 1425.6 & $0.0-11332.4$ & 0.10 \\
\hline Adiponectin $(\mu \mathrm{g} / \mathrm{mL})$ & 53.8 & 32.9 & 44.89 & $13.87-85.46$ & $0.003^{*}$ \\
\hline Leptin $(\mathrm{ng} / \mathrm{mL})$ & 8.73 & 20.77 & 13.84 & $0.0-61.6$ & $0.0001^{*}$ \\
\hline
\end{tabular}

Group (I), BMI $<25 \mathrm{Kg} / \mathrm{m}^{2}, \mathrm{~N}=120$, Male $=55$, Female $=65$

Group (II), BMI $>25 \mathrm{Kg} / \mathrm{m}^{2}, \mathrm{~N}=80$, Male $=39$, Female $=41$

*Significant 
Original Research Article

Table-3: Correlations of different parameters of the study children.

\begin{tabular}{|c|c|c|c|c|c|c|c|c|}
\hline & $\begin{array}{l}\text { Birth- } \\
\text { Weight }\end{array}$ & BMI & Glucose & Insulin & $\begin{array}{l}\text { Homa- } \\
\text { IR }\end{array}$ & CRPhs & Adiponectin & Leptin \\
\hline $\begin{array}{c}\text { BMI } \\
(\mathbf{r}) \\
(\mathbf{p})\end{array}$ & $\begin{array}{c}0.253^{* *} \\
.003\end{array}$ & $\begin{array}{l}1.000 \\
------\end{array}$ & $\begin{array}{c}-.184^{* *} \\
0.010\end{array}$ & $\begin{array}{c}0.163^{*} \\
.019\end{array}$ & $\begin{array}{l}.100 \\
.102\end{array}$ & $\begin{array}{c}.309^{* *} \\
.000\end{array}$ & $\begin{array}{c}-.726^{* *} \\
.000\end{array}$ & $\begin{array}{c}0.468 * * \\
.000\end{array}$ \\
\hline $\begin{array}{l}\text { Glucose } \\
(\mathbf{r}) \\
(\mathbf{p})\end{array}$ & $\begin{array}{c}-.171 * \\
.032\end{array}$ & $\begin{array}{c}-.184^{* * *} \\
.010\end{array}$ & $\begin{array}{c}1.000 \\
-----\end{array}$ & $\begin{array}{c}.195^{* *} \\
.005\end{array}$ & $\begin{array}{c}.288^{* *} \\
.000\end{array}$ & $\begin{array}{l}-.089 \\
.119\end{array}$ & $\begin{array}{l}.161 * \\
.017\end{array}$ & $\begin{array}{c}-.150 * \\
.024\end{array}$ \\
\hline $\begin{array}{l}\text { Insulin } \\
\text { (r) } \\
\text { (p) }\end{array}$ & $\begin{array}{l}-.087 \\
.173\end{array}$ & $\begin{array}{c}.163^{*} \\
.019\end{array}$ & $\begin{array}{c}.195 * * \\
.005\end{array}$ & $\begin{array}{l}1.0000 \\
------\end{array}$ & $\begin{array}{c}.970 * * \\
.000\end{array}$ & $\begin{array}{l}.105 \\
.083\end{array}$ & $\begin{array}{c}-.157^{*} \\
.019\end{array}$ & $\begin{array}{l}.092 \\
.113\end{array}$ \\
\hline $\begin{array}{c}\text { Homa-IR } \\
(\mathbf{r}) \\
(\mathbf{p})\end{array}$ & $\begin{array}{c}-.128 \\
.082\end{array}$ & $\begin{array}{l}.100 \\
.102\end{array}$ & $\begin{array}{c}.288 * * \\
.000\end{array}$ & $\begin{array}{c}.970 * * \\
.000\end{array}$ & 1.000 & $\begin{array}{l}.104 \\
.085\end{array}$ & $\begin{array}{c}-.132 * \\
.040\end{array}$ & $\begin{array}{l}.046 \\
.273\end{array}$ \\
\hline $\begin{array}{c}\text { CRP-hs } \\
\text { (r) } \\
(\mathbf{p}) \\
\end{array}$ & $\begin{array}{l}.069 \\
.229 \\
\end{array}$ & $\begin{array}{c}.309 * * \\
.000 \\
\end{array}$ & $\begin{array}{l}-.089 \\
.119 \\
\end{array}$ & $\begin{array}{l}.105 \\
.083 \\
\end{array}$ & $\begin{array}{l}.104 \\
.085 \\
\end{array}$ & $\begin{array}{l}1.000 \\
----- \\
\end{array}$ & $\begin{array}{c}-.301 * * \\
.000 \\
\end{array}$ & $\begin{array}{c}0.313^{* *} \\
.000 \\
\end{array}$ \\
\hline $\begin{array}{l}\text { Adiponectin } \\
\text { (r) } \\
\text { (p) }\end{array}$ & $\begin{array}{c}-.246^{* *} \\
.004\end{array}$ & $\begin{array}{c}-.726^{* *} \\
.000\end{array}$ & $\begin{array}{c}.161 * \\
.017\end{array}$ & $\begin{array}{c}-.157 * \\
.019\end{array}$ & $\begin{array}{c}-.132 * \\
.040\end{array}$ & $\begin{array}{c}-.301 * * \\
.000\end{array}$ & $\begin{array}{l}1.000 \\
-----\end{array}$ & $\begin{array}{c}-.392 * * \\
.000\end{array}$ \\
\hline $\begin{array}{l}\text { Leptin } \\
\text { (r) } \\
\text { (p) }\end{array}$ & $\begin{array}{l}.102 \\
.135\end{array}$ & $\begin{array}{c}.468 * * \\
.000\end{array}$ & $\begin{array}{c}-.150 * \\
.024\end{array}$ & $\begin{array}{l}.092 \\
.113\end{array}$ & $\begin{array}{l}.046 \\
.273\end{array}$ & $\begin{array}{c}.313^{* *} \\
.000\end{array}$ & $\begin{array}{c}-.392^{* *} \\
.000\end{array}$ & $\begin{array}{l}1.000 \\
----\end{array}$ \\
\hline
\end{tabular}

**Correlation is significant at the 0.001 level (1-tailed).

*Correlation is significant at the 0.05 level (1-tailed).

\section{Discussion}

The main purpose of the present study was to assess the interrelation between birth weight, obesity, glucose tolerance and adipokines of adolescent school children in Pune, India and to predict obesity in adulthood. The children participating in this study were from educated families who lived in an urban setting with relatively middle socio-economic background.

Children with increased birth weight were more obesein their adolescence. They had lower glucose, higher insulin resistance and fat mass. Obesity seems to be due to fat-mass, indicating birth weight are flection of obesity in childhood subsequently leading to obesity in adulthood. Girls were more insulin resistant than boys. Bavdekar. et.al, found that low birth weight children who became obese at the age of 8 years were at higher risk of type II diabetes than those who continued to be remain thin [21] explained as catch-up growth. Yajnik etal, reported that low birth weight children had higher plasma glucose and insulin concentration at $30 \mathrm{~min}$ post glucose load independent of their current size at 8 years of age with no significant difference in fasting glucose [22]. They also reported that mean glucose and insulin concentration were $8.1 \mathrm{mmol} /$ Land $321 \mathrm{pmol} / \mathrm{L}$ in children whose birth weight had been $2.4 \mathrm{~kg}$ or less, compared with birth weight more than $3.0 \mathrm{~kg}$ with the glucose and insulin concentration 7.5mmol/L and $289 \mathrm{pmol} / \mathrm{L}$ respectively. Where as we observed mean glucose and insulin levels of non-obesewere $90.97 \mathrm{mg} / \mathrm{dL}$ and $13.18 \mathrm{IU} / \mathrm{mL}$ respectively with mean birth weighed $2.58 \mathrm{~kg}$, compared with obese group whose mean glucose and insulin were $86.08 \mathrm{mg} / \mathrm{dL} 15.15$ $\mathrm{IU} / \mathrm{mL}$ respectively, whose mean birth weight was $2.8 \mathrm{kgs}$.

The obesity found in $40 \%$ of the study group was due to increased fat mass and higher birth weight. Though there was no significant difference in plasma glucose and insulin between obese and nonobese group, the plasma glucose was lower in obese children with similar insulin levels than normal children indicating insulin insensitivity among obese children which has been derived from 
the homeostatis model assessment [20]. Possible reasons for higher prevalence of obesity in our study are that firstly we studied the semi urban population in Pune town with better health conditions in comparison to rural population. Secondly, our study was limited to the children in schools who were usually from a middle socioeconomic status withless physical activity.

In our study, in the whole group plasma CRP-hs was associated with BMI. However when we compared the CRP-hs concentrations of obese with non-obese, there was no significant difference. This indicates that adipocytes are not involved in production of low grade inflammation i.e. CRP-hs. It also implies that CRP-hs concentrations were not normally distributed among the children studied. Plasma CRP-hs showed strong positive association with leptin and negative association with adiponectin. Several studies are trying to evaluate whether agents traditionally used to improve glycemic control also significantly reduces CRP-hs [23].

Abdulla et al, found that $76 \%$ of obese children had very high CRP-hs levels indicating inflammatory process [24]. Although adiponectin levels did not correlate with CRP-hs levels, we observed dichotomous relationships of adiponectin and CRPhs levels with generalized and abdominal obesity. We conclude that generalized obesity affects the adiponectin-insulin relationship in post pubertal Asian Indian males; however, the relationship of adiponectin with CRP-hs needs further evaluation [25].

Leptin is considered to be the missing link between obesity and diabetes, as it has been shown to regulate blood sugar via its control on appetite and fat storage. In our study, there was no significant correlation between birth weight and leptin but BMI shows a significant positive correlation with leptin. Leptin, showed a highly significant rise with increasing BMI $(\mathrm{p}<0.01)$; [24, 26].

Abdulla et al [24] and Park et al [26] reported a strong association of obesity with leptin and birth weight indicated the relation with current BMI and Naval etala and Marchini et al [25, 27] with maternal nutritional status during the conception of these children. We found obese children had higher plasma leptin concentrations indicating the presence of higher fat mass. Jornayvazet al have reported a correlation between leptin with body fat, body mass index and waist circumference [28]. Similarly, Masoud Y Al Maskariet al, found that a strong significant positive correlation between leptin levels and BMI [29]. Aaron R etalstudied the association of leptin with BMI and found that adiposity determinedleptin but leptin deficiency did not play an important role in obesity in the studied population [30].

Where as Jornayvaz et al found that adult leptin levels decreased consistently with increased birth weight. Overall, the decrease in leptin levels with birth weight suggest that the mechanisms by which low or high birth weight influence the development of obesity in later life might be different.

Interestingly, it has been suggested that children born with a low weight develop high leptin levels during catch-up growth [28]. Salbe et al reported childhood obesity to be the dominant predictor of obesity 5 yrs later in life. These results suggest that the strategies to prevent childhood obesity must be initiated at a very early age [32].

They have also found that fasting insulin concentration at 5yrs of age was a negative determinant of percentage of body fat and fasting leptin concentration was positive determinant of subsequent percentage of body fat. They found that children with higher fasting leptin concentration at base line were fatter and heavier at follow up. However, in our study leptin concentration was not associated with birth weight. Singhal et al found association of low birth weight with higher leptin concentration relative to fat mass suggesting that leptin physiology is programmable [33].

Obese children with reduced adiponectin levels were closely associated with insulin resistance. In this study we observed that obese children had low levels of adiponectin $(\mathrm{p} \leq 0.003)$ which is in concordance with Arita Y et al. and M. K. Garg et al and Kuo et al who also found that adiponectin concentration was lower in obese subjects as compared to non-obese subjects [34-36]. On the contrary Hung et alreported an association of circulating adiponectin levels with inflammatory markers, insulin resistance and metabolic syndrome independent of obesity [37]. Lele R D et al, showed an inverse association of Adiponectin with obesity 
and its indices (BMI and waist circumference) and strongly with insulin resistance. Indeed, intervention studies have shown increase in adiponectin values with weight loss [38]. The low adiponectin levels indicate the need andscope for therapeutic interventions aimed at raising the level.

Intake of diets rich in essential fatty acidsprotect against insulin resistance and obesity in rodents and increase insulin sensitivity in human [39]. In our study females had significantly higher BMI $(\mathrm{p} \leq 0.045)$ than males, supported by significantly lower levels of adiponectin $(p \leq 0.007)$. On the contrary Antje Bottner et al. found thatadiponectin levels progressively decline with physical and pubertal development, especially in boys.

One major finding of his study was that adiponectin levels decrease in parallel with the progression through puberty in boys, but this is not as pronounced in girls. The decline was significantly related to plasma androgen levels and subsequently leads to lower adiponectin levels in adolescent boys compared with girls after completion of puberty [40].

Limitations: We excluded adolescents who were not attending school. Children who attend school are likely to come from backgrounds that represent better education and, therefore, the study subjects may not be representative of the wider population.

Adiponectin circulates in different molecular weight complexes, and it appears that it is the high molecular weight (HMW) isoforms are more relevant in the prediction of insulin resistance $[41,42]$.

Although a high correlation between HMW and total adiponectin has been demonstrated, future studies which can assess the HMW-to-total adiponectin ratio may be more informative.

\section{Conclusion}

Better maternal nutrition during pregnancy has lead to increased birth weight and off spring obesity and increased fat mass leading to obesity in these children when they were in-utero cannot be ruled out. Birth weight is responsible for obesity and insulin resistance. However, the relationship of birth weight and adipokines needs further evaluation.
Original Research Article

Funding: Nil, Conflict of interest: None

Permission of IRB: Yes

\section{References}

1. Leeson CP, Kattenhorn M, Morley R, Lucas A, Deanfield JE. Impact of low birth weight and cardiovascular risk factors on end othelial function in earlyadult life. Circulation. 2001 Mar 6;103 (9): 1264-8.

2. Lucas A. Programming by early nutrition in man. In: Bock GR, Whelan J, editors. The childhood environment and adult disease. Chichester: Wiley; 1991. pp. 38-55. CIBA Foundation Symposium 156.

3. Johan G. Eriksson, Tom J. Forsen, Clive Osmond, and David J.P. Barker, Pathways of infant and childhood growth that lead to type 2 Diabetes. Diabetes Care 2003 Nov; 26 (11): 3006-3010. Available from: https://doi.org/10.2337/diacare.26. 11.3006 .

4. Barker D.J.P. (1998). Mothers, Babies \& health in later life, $2^{\text {nd }}$ ed. Edinburgh: Churchill Livingstone. Hales CN, Barker DJP. Type 2 (non-insulin dependent) diabetes mellitus: the thrifty phenotype hypothesis. Diabetologia 1992 Jul; 35(7): 595-601. Diabetologia1992Jul;35:595-601.doi: 10.1007/BF 00400248.

5. Hales CN, Barker DJP. Type 2 (non-insulin dependent) diabetes mellitus: the thrifty phenotype hypothesis. Diabetologia 1992 Jul; 35(7): 595-601. Diabetologia1992Jul;35:595-601.doi: 10.1007/BF 00400248.

6. Ravussin E, Gautier JF. Metabolicpredictors of weight gain. Int J Obes Relat Metab Disord.1999 Feb; 23 Suppl 1:37-41.

7. Ramachandran A. Specific problems of the diabetic foot in developing countries. Diabetes Metab Res Rev.2004 May-Jun; 20 Suppl 1: S19-22.

8. Cruz, Miguel, RebecaGarcía-Macedo, Yolanda García-Valerio, Margarita Gutierrez, Rafael Medina- Navarro, Genoveva Duran, Niels Wacher, and JesúsKumate. "Low adiponectin levels predict type 2 diabetes in Mexican children." Diabetes care 27, no. 6 (2004): 1451-1453. 
Original Research Article

9. Asayama K, Hayashibe H, Dobashi K, Uchida N, Nakane T, Kodera K, Shirahata A, Taniyama M. Decrease in serum adiponectin level due to obesity and visceral fat accumulation in children. Obes Res. 2003 Sep;11(9):1072-9.

10. Bacha F, Saad R, Gungor N, Arslanian SA. Adiponectin in youth: relationship to visceraldiposity, insulin sensitivity, and beta-cell function. Diabetes Care.2004 Feb;27(2):547-52.

11. Bush NC, Darnell BE, Oster RA, Goran MI, Gower BA Adiponectin is lower among African Americans and is independently related to insulin sensitivity in children and adolescents. Diabetes 2005, 554:2772-2778.

12. Weiss R, Dufour S, Groszmann A, Petersen K, Dziura J, Taksali SE, Shulman G, Caprio S. Lowadiponectin levels in adolescent obesity: a marker of increase dintramyocellular lipidaccumulation. J Clin Endocrinol Metab.2003 May; 88 (5):2014-8.

13. Degawa-Yamauchi M, Dilts JR, Bovenkerk JE, Saha C, Pratt JH, Considine RV. Lower serum adiponectin levels in African-American boys. Obes Res. 2003 Nov;11(11):1384-90.

14. StefanN, BuntJC, SalbeAD, FunahashiT, MatsuzawaY, Tataranni PA, Plasma adiponectin concentrations in children: relationships with obesity and insulinemia. J Clin Endocrinol Metab 2002, 87: 4652-4656.

15. Tsou PL, Jiang YD, Chang CC, Wei JN, Sung FC, Lin CC, Chiang CC, Tai TY, Chuang LM. Sexrelated differences between adiponectin and insulin resistance in schoolchildren. Diabetes Care 2004, 27:308-313.

16. Vikram NK, Misra A, Pandey RM, Dwivedi M, Luthra K. Adiponectin, insulin resistance, and Creactive protein in post pubertal Asian Indian adolescents. Metabolism. 2004 Oct; 53 (10): 1336-41.

17. Atul Singhal, Nigel Jamieson, Mary Fewtrell, John Deanfield, Alan Lucas, and NaveedSattar, Adiponectin Predicts Insulin Resistance But Not Endothelial Function in Young, Healthy Adolescents, The Journal of Clinical Endocrinology
\& Metabolism 90(8):4615-4621 The Endocrine Society doi: 2006,10.1210/jc.2005-0131.

18. WHO Expert Consultation. Appropriate bodymass index for Asian populations and its implications for policy and intervention strategies. Lancet. 2004 Jan 10;363(9403):157-63.

19. McKeigue PM, Shah B, Marmot MG. Relation of central obesity and insulin resistance with highdiabetesprevalence and cardiovascularrisk in SouthAsians. Lancet.1991Feb16;337(8738):382-6.

20. Matthews DR, Hosker JP, Rudenski AS, Naylor BA, Treacher DF, Turner RC. Home ostasismodel assessment: insulin resistance and beta-cellfunction from fasting plasmaglucose and insulin concentrations in man. Diabetologia.1985 Jul;28 (7): 412-9.

21. Ashish Bavdekar, Chittaranjan S. Yajnik, Caroline H.D. Fall, Swatee Bapat, Anand N. Pandit, Vaishali Deshpande, Sheila Bhave, Sam D. Kellingray, and Charu Joglekar. Insulin Resistance Syndrome in 8-year old Indian children, Small at Birth, Big at 8 Years, or Both? Diabetes, Vol. 48, December 1999 2422-2429.http://diabetes. diabetes journals.org/content/48/12/2422.short

22. Yajnik CS, Fall $\mathrm{CH}$, Vaidya U, Pandit AN, Bavdekar A, Bhat DS, Osmond C, Hales CN, Barker DJ. Fetal growth and glucose and insulin metabolism in four-year-oldIndianchildren. Diabet Med.1995 Apr;12(4):330-6.

23. Ndumele CE, Pradhan AD, Ridker PM. Interrelationships between inflammation, Creactive protein, and insulin resistance. $\mathrm{J}$ Cardiometab Syndr. 2006 Summer;1(3):190-6.

24. Abdullah AR, Hasan HA, Raigangar VL. Analysis of the relationship of leptin, highsensitivity C-reactive protein, adiponectin, insulin, and uric acid to metabolic syndrome in lean, overweight, and obeseyoungfemales. Metab Syn dr Relat Disord. 2009 Feb;7(1):17-22. doi: 10. 1089/met. 2008.0045.

25. Vikram NK, Misra A, Pandey RM, Dwivedi M, Luthra K. Adiponectin,insulin resistance, and Creactive protein in postpubertal Asian Indian adolescents. Metabolism.2004 Oct;53(10):1336-41. 
Original Research Article

26. Park J.E., H.J. Choi, I.K. Kim, H.J. Lee, J.H. Kang c , J. Song. Influence of serum leptin levels on future overweight risk in Korean children. Nutrition, Metabolism \& Cardiovascular Diseases (2012) 22, 260-268 doi:10.1016/j.numecd. 2010. 08.010 .

27. Marchini G, Fried G, Ostlund E, Hagenäs L. Plasma leptin in infants: relations to birth weight and weight loss. Pediatrics. 1998 Mar;101(3 Pt 1): 429-32.

28. Jornayvaz FR, Vollenweider P, Bochud M, Mooser V, Waeber G, Marques-Vidal P. Low birth weightleads to obesity, diabetes and increase dleptinlevels in adults: the Co Lausstudy. Cardiovasc Diabetol. 2016 May 3;15:73. doi: 10. 1186/s12933-016-0389-2.

29. Masoud Y A Maskari, Adel A Alnaqdy, Correlation between Serum Leptin Levels, Body Mass Index and Obesity in Omanis. sultanqaboos university medical journal, December 2006 vol 6, no. 2, Sultan Qaboos University@.

30. Aaron R. Folsom, Michael D. Jensen, t David R. Jacobs, Jr, Joan E. Hilner.z Albert W. Tsai, and Pamela J. Schreiner. Serum Leptin and Weight Gain Over 8 Years in African American and Caucasian Young Adults. Obesity research Vol. 7 No. 1 Jan, 19991-8.

31. Jaquet D, Leger J, Tabone MD, Czernichow $\mathrm{P}$, Levy-Marchal C. High serum leptin concentrations during catch-upgrowth of childrenborn with intrauterine growth retardation. J Clin Endocrinol Metab. 1999 Jun;84(6):1949-53.

32. Salbe AD,CWeyer, Lindsay RS, Ravussin E, Takarranni PA. Assessing risk factors for obesity between childhood and adolescence: Birth weight, childhood adiposity, parental obesity, insulin and leptin. Paediatrics, 110:299-306. 2002.doi:10. 1542/peds. 110.2.307.

33. Singhal A, Farooqi IS, O'Rahilly S, Cole TJ, Fewtrell M, Lucas A. Early nutrition and leptin concentrations in later life. Am J Clin Nutr. 2002 Jun;75(6):993-9.

34. Arita Y, Kihara S, Ouchi N, Takahashi M, Maeda K, Miyagawa J, Hotta K, Shimomura I,
Nakamura T, Miyaoka K, Kuriyama H, Nishida M, Yamashita S, Okubo K, Matsubara K, Muraguchi M, Ohmoto Y, Funahashi T, Matsuzawa Y. Paradoxical decrease of an adipose-specificprotein, adiponectin, in obesity. Biochem Biophys Res Commun. 1999 Apr 2;257(1):79-83.

35. Garg M. K., M. K. Dutta, Namita Mahalle, Adipokines (adiponectin and plasminogen activator inhhibitor-1) in metabolic syndrome, Indian Journal of Endocrinology and Metabolism / Jan-Feb 2012 / Vol 16 | Issue 1, Available from http://www.ijem.in on Thursday, January 21, 2016, IP: 14.139.123. 242]. doi: 10.4103/2230-8210.91206.

36. Kuo SM, Halpern MM. Lack of association between body mass index and plasma adiponectin levels in healthy adults. Int J Obes (Lond). 2011 Dec; 35(12):1487-94. doi: 10.1038/ijo.2011.20. Epub 2011 Mar 1.

37. Hung J, BM McQuillan, PL Thompson and JP Beilby, Circulating adiponectin levels associate with inflammatory markers, insulin resistance and metabolic syndrome independent of obesity, International Journal of Obesity 32, 772-779 (2008).

38. Lele RD, Shashank R Joshi, Arpita Gupte, Association of Adipocytokines(Leptin, Adiponectin TNF-alpha), Insulin and Proinsulin with Diabetes The Mumbai Obesity Project [MOP]JAPI VOL. 54 SEPTEMBER 2006 (689-696).

39. Flachs P, Mohamed-Ali V, Horakova O, Rossmeisl M, Hosseinzadeh-Attar MJ, Hensler M, Ruzickova J, Kopecky J. Polyunsaturated fatty acids of marine origin induce adiponectin in mice fed a high-fat diet. Diabetologia. 2006 Feb;49(2): 394-7. Epub 2006 Jan 6.

40. Antje Bottner Jurgen Kratzsch Grit Muller Thomas M. Kapellen Susann Bluher Eberhard Keller Matthias Bluher Wieland Kiess, Gender Differences of Adiponectin Levels Develop during the Progression of Puberty and Are Related to Serum Androgen Levels.

The Journal of Clinical Endocrinology \& Metabolism, Volume 89, Issue8, 1 August 2004, Pages 4053-4061, https:// doi.org/ 10. 1210/jc. 2004-0303. 
Original Research Article

41. Matsuzawa Y. Adiponectin: Identification, physiology and clinical relevance in metabolic and vascular disease. Atheroscler Suppl. 2005 May; 6 (2):7-14.
42. Kadowaki T, Yamauchi T, Kubota N, Hara K, Ueki K, Tobe K. Adiponectin and adiponectin receptors in insulin resistance, diabetes, and the metabolic syndrome. J Clin Invest. 2006 Jul; 116 (7):1784-92.

\section{How to cite this article?}

Thakre R.R, Naik S.S, Abhang A.S. Interrelation between birth weight, body mass index, insulin resistance, CReactive Protein-hs, adiponectin and leptin in children (Age 10 to 20 years). Int J Med Res Rev 2017;5 (12):982-990.doi:10.17511/ijmrr. 2017.i12.03 